Japygidæ. Counting thoracic and abdominal segments all as postcephalic, the most posterior position of the gonopores in Progoneate types is the fourth postcephalic segment, while the most anterior position in Opisthogoneate types is actually the eighth, in Collembola. Thus both types can be simply derived from an original ancestor which possessed only five pairs of gonads, in the fourth to eighth postcephalic segments respectively. These must be conceived of as having originally opened segmentally by paired gonopores. The linking up of the gonads on each side by paired gonoducts, to open into the fourth postcephalic segment only, gave the primitive progoneate condition, while a similar linking, with backward opening into the eighth, gave the primitive opisthogoneate condition, as in Collembola.

The conclusions arrived at by the above three lines of analysis are so closely similar that it is possible to exhibit them all in a single phyletic diagram (Fig. 1). The original common ancestor of myriopods and insects must have differed from the Onychophora in not being epimorphic and in having fewer body segments. This common ancestor, the Protaptera, would have merited the status of a class. It divided, first of all, into progoneate and opisthogoneate forms ; and, very soon after, the opisthogoneate types divided into Myriopoda Opisthogoneata and true Insecta or Hexapoda. The Collembola are the only remaining remnant of all the ancient protomorphic types. They were quite well developed in the Lower Devonian. The progoneate types culminated in the higher diplopods, leaving the pauropods on one hand and the Symphyla on the other as lowly anamorphic types. The opisthogoneate myriopods ran out into the higher Chilipoda, which are epimorphic ; but, while still anamorphic, they gave rise to another highly evolved type, the Schizotarsia, with annulate legs and large compound eyes. The hexapod or insect line, leaving the Collembola and Protura far behind as lowly side-branches, ran rapidly through the Thysanura Entotrophica to the Thysanura Ectotrophica, and so to the winged forms of Pterygota, probably somewhere in the Carboniferous.

The probable geological horizon of the hypothetical ancestral Protaptera is Upper Silurian, and their ecology is that of terrestrial forms dwelling in moist places and feeding on primitive plant life.

\title{
Progress in Education and Research in Agriculture and Fisheries.
}

$\mathrm{I}^{\mathrm{N}}$ NCREASING recognition is being given to the fact that many problems connected with agriculture need the help of the trained research worker as well as that of the practical man. During the last twenty years, since the appointment of the Development Commission, steady and rapid progress has been made, until at the present time the ramifications of the system of research and advisory work set up by that body extend over a surprising variety of problems. Three reports recently issued, one by the Development Commissioners, and two by the Ministry of Agriculture on agricultural research institutes and research and education respectively, present a comprehensive picture of the existing state of affairs in Great Britain.

The report of the Development Commission* falls into four sections, the first two of which relate to the grants which have been recommended for the development of agriculture, rural economy, fisheries, and harbours, and describe the purposes for which these advances are being used. The third part of the report relates to action taken under Part 2 of the Act of 1909 in connexion with the compulsory acquisition of land for road improvements. The fourth part deals with the financial position of the Development Fund at the end of the year 1929-30. The advances recommended from the fund amounted to $£ 721,653$, as against $£ 394,752$ in the previous year. The large increase for agriculture and fisheries is attributable to recommendations for capital expenditure out of a special grant of $£ 500,000$ made for unemployment relief. Schemes relating to fishery harbours and

* Development Commission. Twentieth Report of the Development Commissioners, being for the Year ended the 31st March 1930 Pp. 247. (London: H.M. Stationery Office, 1930.) 3s. 6d. net. reclamation are receiving special attention, and any economic schemes of reclamation which may be put forward will receive favourable consideration.

Among the activities of the Commission, those dealing with the development of the countryside make a wide appeal. Rural industries are being aided and developed in thirteen counties by means of grants to be expended according to local needs for the organisation of classes and the staging of exhibits at shows. Some counties now have permanent showrooms for exhibiting craftsmen's goods. The building of village halls is much encouraged by a system of loans which has now been thrown open to the whole country by the establishment of ad hoc committees in counties not having a community council. The success of the scheme is such that in the first three months of 1929,279 villages made inquiries as to loans, and during that period fourteen loans, amounting in all to $£ 3833$, were approved.

Another feature of the year's work of the Development Commission has been the adoption of methods for the relief of the fishing industry by remission of debts and by reconditioning of harbours with the view of the development of fisheries. A total sum of $£ 34,770$ was recommended during 1929-30 for the maintenance of fishery research. The grants are for 'directed ' researches, deliberately planned to find a solution of problems affecting the commercial fisheries, and 'free' researches, the object of which is to advance that knowledge of marine life in relation to its whole environment upon which the solution of practical problems ultimately depends. The fisheries section of the report sets forth much interesting information, and is calculated to surprise the average reader by the

No. 3191, VoL. 126] 
extent and variety of the attempts to improve our knowledge of matters appertaining to the important sources of food in river and sea.

The position of affairs relating to agricultural research is set out more fully in the report issued by the Ministry of Agriculture and Fisheries.* Here, again, it is obvious that a very wide field is being surveyed, and that a multitude of problems relating to agriculture in the widest sense are being probed. These investigations are nearly all carried out at the research institutes and at advisory centres, by specially appointed staffs. It is searcely possible to give even the briefest outline of the activities of the stations, which range from every aspect of plant and animal growth in health and disease to problems of agricultural economics, engineering, food preservation, and transport. The main lines of research in progress are indicated in a series of short reports drawn up by the heads of the various institutes, but of necessity they can do little more than indicate the object of the experimental work and the more striking of the results already obtained. It is apparent that steady progress is being made and much valuable information obtained and disseminated, the output apparently being limited only by the staff and money available. The attempt to establish Spartina townsendii (rice grass) in Essex is interesting. The primary object is to prevent coast erosion, other considerations being the provision of a supply of seed to meet overseas demands and the establishment of a.crop which could be used as an emergency feed for stock and to provide material for examining other economic possibilities of the plant. Attempts at overseas transport have shown that seed is unsatisfactory for long journeys involving passage through the tropics, but that cuttings can be successfully carried so far as Singapore if shipped in cool chambers between $30^{\circ}$ and $40^{\circ} \mathrm{F}$.

Fluctuations in the number of wild rodents are of importance on account of the economic effects of these animals on agriculture and forestry. The co-operation of numerous observers throughout the country has been enlisted to obtain data about cycles in numbers of field mice and squirrels, the cyclical variation being apparently affected by disease and by certain climatic factors as yet not properly understood.

The other report issued by the Ministry of Agriculture and Fisheriest indicates a gradual but steady expansion of the system of agricultural research and education in Great Britain, this being regarded as convincing proof that a genuine need of agriculture in the country is being met by this means.

Agricultural research owes much to the financial aid received from the Empire Marketing Board, which has facilitated considerable extension during the past few years. In 1929 the expenditure on re-

* Ministry of Agriculture and Fisheries, Fepartment of Agrieulture for Scotland, and Ministry of Agriculture for Northern Ireland. Reports on the Work of Agricultural Research Institutes and on certain other Agricultural Investigations in the United Kingdom, 1928-29. other Agricultural Investigations in the United Kingdo
Pp. 247. (London: H.M. Stationery Oflee, 1930.) n.p.

Pp. 47 . Ministry of A griculture and Fisheries. Report on the Work of the Re Ministry of Agriculture and Eisheries. Report on the Work of the (London. H is Stationery Office, 1930) lo. oll net.

No. 3191, VoL. 126] search from all sources amounted to $£ 19,694$ on capital account and $£ 288,012$ for maintenance grants, more than half of the expenditure taking the form of grants to research institutes. The most important single development has been the formation of eight Imperial bureaux, which have been established in close connexion with existing research institutes. These deal with soil science, animal nutrition, animal health, animal genetics, agricultural parasitology, plant genetics (herbage plants and others), and fruit production. It already seems certain that the opportunities thus afforded for mutual interchange of ideas and information will benefit British agriculturists as well as overseas workers.

Attention is directed to the serious scarcity of students, trained in biological science, capable of filling the various posts in the Empire which from time to time offer themselves; special steps have since been taken to attempt to remedy this by increased publicity of the possible opportunities awaiting trained biologists.

The report, as a whole, confines its attention to an outline of the position of the Ministry's various activities with regard to agricultural research, local investigations and advisory work, scholarships, and provision of technical advice. Detailed accounts of the scientific results are not included, as they are published elsewhere.

Agricultural education during 1928-29 continued to make steady progress, but showed no features of outstanding importance. Special attention was devoted to the problem of providing suitable agricultural instruction for country boys and girls between the ages of fourteen and sixteen years, and certain experimental courses in Shropshire met with such success that the possibility of more extended schemes has come under consideration. Further success has attended the Ministry's recognition of farm household management as a branch of agricultural education, scholarships being provided at certain institutes.

Improvements in the position of veterinary science are overdue, and proposals have been put forward for the reconstruction of the Royal Veterinary College with the view of establishing the work on a sound basis, the recommendations being very far-reaching.

The progress of dairy education is reflected in the rapid improvement in the milk supply throughout England, the producer, on the whole, turning out a much higher grade product than formerly. As a result, the interest of sanitary inspectors has been aroused, and many of these are endeavouring to keep in touch with the dairy instructors.

Horticultural education is steadily increasing, and during 1929 two more county authorities began to provide facilities in this respect. A noteworthy advance has been made with regard to instruction in the cultivation of crops under glass, as complete courses of practical and technical instruction for the commercial glasshouse industry have been established by the Herts education authority, in co-operation with the Lea Valley Growers' Association. Bulb-growing provides an example of a 
highly specialised industry which is benefiting by county and Government assistance, comprehensive trials and experiments dealing with problems peculiar to the industry being carried out in various centres, notably Scilly, Cornwall, and Lincolnshire.

On the advisory side, continued progress has been made in the inspection and certification of growing crops, chiefly potatoes, strawberries, and black currants; of goods intended for export, including nursery stock; and in the enforcement of the various orders against destructive insects and pests. The value of this phase of work is enhanced by the stringent import regulations in force in many other countries, as it is most important that the high reputation of the English certificate of health should be maintained.

\section{News and Views.}

THE following sectional presidents have been appointed for the centenary meeting of the British Association, to be held in London on Sept. 23-30 next year, under the presidency of General Smuts : Section A (Mathematical and Physical Sciences), Sir J. J. Thompson; Section B (Chemistry), Sir Harold Hartley; Section C (Geology), Prof. J. W. Gregory; Section D (Zoology), Prof. E. B. Poulton; Section E (Geography), Sir Halford Mackinder; Section F (Economic Science and Statistics), Prof. E. Cannan; Section G (Engineering), Sir J. Alfred Ewing; Section H (Anthropology), Prof. A. R. Radeliffe-Brown; Section I (Physiology), Dr. H. H. Dale; Section J (Psychology), Dr. C. S. Myers ; Section K (Botany), Prof. T. G. Hill ; Section L (Educational Science), Sir Charles Grant Robertson; Section M. (Agriculture), Sir John Russell. On Wednesday, Sept. 23, the ceremony of installing General Smuts as president of the Association, and a reception of delegates, will be held in the Albert Hall during a private view of the exhibition which is being arranged in connexion with the Faraday centenary celebrations, and will be open, for this occasion, to members of the British Association.

DyestuFrs have occupied considerable attention in Parliament recently, the debates incidentally directing the limelight of public attention on to the part played by organic chemistry in framing the nation's destiny. In the House of Commons on Dec. 17, the Government's majority in favour of allowing the Dyestuffs (Import Regulation) Act, 1920 , to lapse next month had fallen from thirty to six-a small number, seeing that $\mathbf{4 8 2}$ members voted, but sufficient to reject the amendment inserted by the House of Lords in the Expiring Laws Continuance Bill. Mr. Graham, the President of the Board of Trade, disagreed with the view that opportunity for further inquiry was necessary, holding that there has already been made a full and impartial review of the case by the Dyestuffs Industry Development Committee, which was representative of both dye manufacturers and dye users. This committee was unable to give any clear direction to the Government; the decision of the latter, he said, was well founded and should be maintained. Sir P. Cunliffe-Lister said that the committee's report urged the Government to pursue inquiries further and endeavour to reach agreement between makers and users as to the measure of protection necessary and the form which it should take. He challenged the Government to disclose the views of the Service departments, and declared that a substantial section of dye users opposed the lapse of the Act. Sir H. Samuel again opposed the continuance of the Act; is there any probability, he asked, that a new inquiry will lead to any more agreed and unanimous a report than that which has already been issued ?

LABOUR members were not solidly ranged in support of the Government's attitude; Mr. 'Wise, Mr. Denman, Major Church, and Mr. Strachey advised acceptance of the Lords' proposal to continue the Act for one year. Mr. Wise expressed his belief that the growth of the dyestuffs industry in Great Britain has had very valuable effects on research, but he doubted whether all is being done that might be expected. It would be in the best interests of British industry and the vital interests concerned in dyes and chemicals if the Act were continued for a short period. Mr. Denman said that we need more experiment ; we have shown ourselves intolerant of experiments and drop them at the moment when they are becoming interesting and worth continuing. $\mathrm{He}$ advised a test of the new conditions, followed by an inquiry, before a final decision was reached. Major Church said that virtually every scientific body in the country has condemned the non-continuance of the Act. With one accord eminent scientific workers at the Bristol meeting of the British Association last September suggested that it would be an act of incredible folly to withdraw the protection which has been given to our dye industry, and he did not think the House could afford to ignore the considered opinion of that body. Mr. Strachey declared that if Britain is to survive as an industrial nation, it will be primarily by the development and application of science throughout the industrial and economic system, and the action of the Government would attack the interests of science both directly and indirectly by allowing the Act to lapse. Speeches in favour of temporary continuation of the Act were delivered by Mr. Remer, Sir H. Croft, Mr. Marjoribanks, Mr. E. D. Simon, and Sir R. Horne, whilst Mr. J. H. Hudson, Sir D. Maclean, and Mr. Shaw opposed it; the Secretary of State for War (Mr. Shaw) admitted that the experts in his department advised that it is essential to maintain a chemical research industry, and that, failing it, there must be something comparable to safeguard the country.

INSISTING on its amendment, which has the effect of continuing the Dyestuffs (Import Regulation) Act for another year, the House of Lords on Dec. $18 \mathrm{re-}$ turned the Expiring Laws Continuance Bill to the

No. 3191, VoL. 126] 